\title{
Effect of nitrogen fertilizer and weed management on the yield of transplant aman rice
}

\author{
Jyoti Adhikari ${ }^{1}$, Md. Abdur Rahman Sarkar ${ }^{1}$, Md. Romij Uddin ${ }^{1}$, Uttam Kumer Sarker ${ }^{1}$, Kawsar \\ Hossen $^{2}$ and Umme Rosemila ${ }^{3}$
}

${ }^{1}$ Department of Agronomy, Bangladesh Agricultural University, Mymensingh-2202, Bangladesh

${ }^{2}$ Department of Agriculture, Noakhali Science and Technology University, Noakhali, Bangladesh

${ }^{3}$ Department of Biotechnology, Bangladesh Agricultural University, Mymensingh-2202, Bangladesh

\begin{tabular}{|c|c|}
\hline ARTICLE INFO & Abstract \\
\hline Accepted: 01 January 2018 & \multirow{3}{*}{ 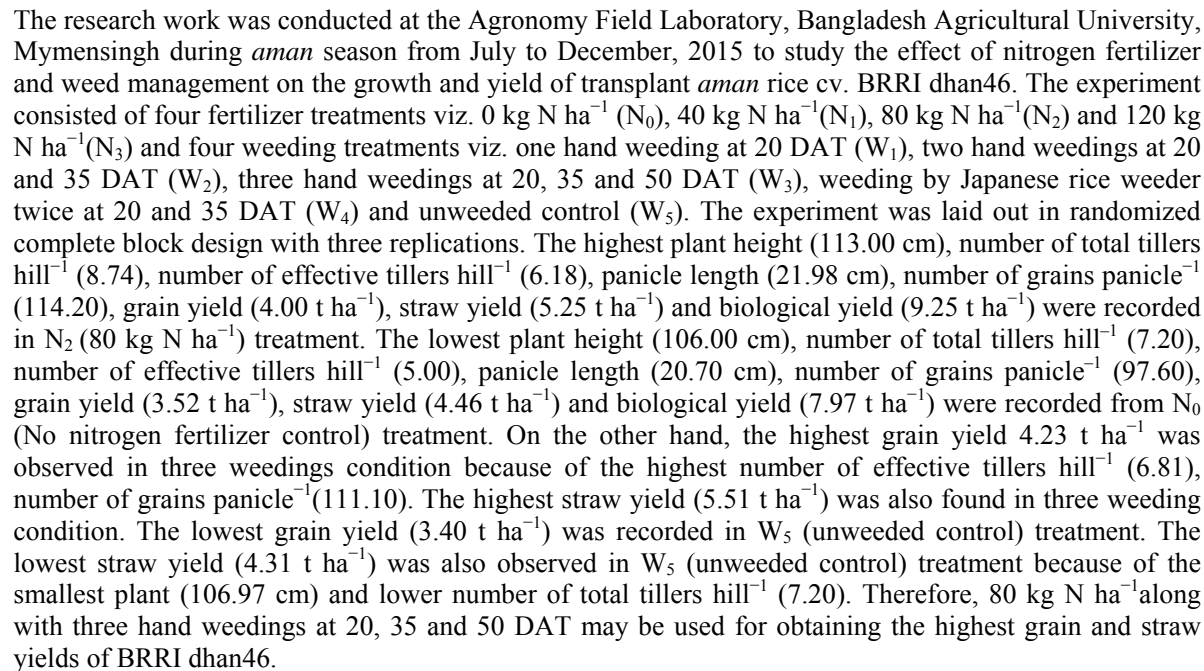 } \\
\hline $\begin{array}{l}\text { Keywords: } \\
\text { Nitrogen management, weeding, } \\
\text { anweeded control, yield and } \\
\text { harvest index }\end{array}$ & \\
\hline romijagron@bau.edu.bd) & \\
\hline
\end{tabular}

\section{Introduction}

Agriculture is the largest employment sector in Bangladesh. As of 2016, it employs $47 \%$ of the total labor force and comprises $16 \%$ of the country's GDP. The performance of this sector has an overwhelming impact on major macroeconomic objectives like employment generation, poverty alleviation, human resources development and food security. A plurality of Bangladeshis earns their living from agriculture. Rice is the dominant staple food for many countries of the world (Mobasser et al., 2007). It is also the most important food crop and a major food grain for more than one third of the world population (Zhao et al., 2011).

Nitrogen is the key element in the production of rice and gives by far the largest response. It is an essential plant nutrient that plays a significant role in growth, yield and quality of rice. The important role of nitrogen fertilizers in increasing rice yields has been widely recognized, particularly after the development of modern varieties. Nitrogen is an integral part of protoplasm, protein and chlorophyll and plays a remarkable role in increasing cell size which in turn increases yield. Excess amount of nitrogenous fertilizer results in lodging of plants, prolonging growing period, delayed in maturity, susceptibility to insect-pests and diseases and ultimately reduces yield (Uddin, 2003). Efficient fertilizer management gave higher yield of crop and reduced fertilizer cost (Hossain and Islam, 2006). Plant growth is seriously hampered when lower dose of nitrogen is applied, which drastically reduces the yield. It is also a fact that improper use of nitrogenous fertilizer, instead of giving yield advantage, may reduce the same. Many workers have reported a significant response of rice to nitrogen in different soils in Bangladesh (Bhuiya et al., 1989, Hussain et al., 1989 and Islam et al., 1990).

Weeds are one of the most important agricultural pests. Infestation of weed is one of the most important causes for low yield of rice. There is no doubt that maximum benefit from costly input like fertilizers and pesticides in rice can be fully derived when the crop is kept free from weed infestation. The edaphic and climatic conditions of the country are congenial for the growth of numerous species of obnoxious weeds, which lead to considerable 
yield reduction. High competitive ability of weeds exerts a serious negative effect on crop production causing significant losses in crop yield (Mamun et al., 1993).Poor weed control is one of the major factors for yield reduction in rice, the extent of which depends on type of weed flora and their intensity of infestation. Yield losses due to weed infestation are greater than the combined losses of insect pests and diseases. In Bangladesh, weed infestation reduces grain yield by about $70-80 \%$ in aus rice, $30-40 \%$ for transplanted $(\mathrm{T})$ aman rice and $22-36 \%$ for modern boro rice cultivars (BRRI, 2008; Mamun, 1990). There are studies about nitrogen and weed management in T. aman rice but for a specific variety BRRI dhan 46 it is rare. Thus the best weeding needs to be adopted by the farmers with a view to reducing weed infestation and maximizing rice yield. Considering mentioned points, the study was conducted to optimize nitrogen and weed management in transplant aman rice.

\section{Materials and Methods}

The experiment was conducted at the Agronomy Field Laboratory, Bangladesh Agricultural University (BAU), Mymensingh during the period from July to December, 2015 to study the effect of nitrogen fertilizer and weed management on the growth and yield of transplant aman rice. The experimental site belongs to the Old Brahmaputra Floodplain Agro ecological Zone (AEZ-9). Non calcareous dark-grey floodplain soil is generally predominant in the site. The land type was medium high and the soil was silty loam in texture. The $\mathrm{pH}$ value of the soil was 6.8 and the soil is low in organic matter content. The variety BRRI dhan 46 was used as the test crop in the experiment. BRRI dhan 46 with photoperiod sensitivity is suitable for late transplanting in aman season after the recession of flood water. Its average grain yield is 4.7 tha $^{-1}$. The experiment consisted of 4 levels of Nitrogen viz. $0 \mathrm{~kg} \mathrm{~N} h a^{-1}\left(\mathrm{~N}_{0}\right), 40 \mathrm{~kg} \mathrm{~N} \mathrm{ha}^{-1}$ $\left(\mathrm{N}_{1}\right), 80 \mathrm{~kg} \mathrm{~N} \mathrm{ha}^{-1}\left(\mathrm{~N}_{2}\right)$ and $120 \mathrm{~kg} \mathrm{~N} \mathrm{ha}^{-1}\left(\mathrm{~N}_{3}\right)$ and five weeding treatments viz. One hand weeding at 20 DAT $\left(\mathrm{W}_{1}\right)$, two hand weedings at 20 and $35 \mathrm{DAT}\left(\mathrm{W}_{2}\right)$, three hand weedings at 20,35 and $50 \mathrm{DAT}\left(\mathrm{W}_{3}\right)$, weeding by Japanese rice weeder twice at 20 and $35 \mathrm{DAT}\left(\mathrm{W}_{4}\right)$ and unweeded control $\left(\mathrm{W}_{5}\right)$. The experiment was laid out in a randomized complete block design with three replications. Each block was divided into twenty unit plots of size $4.0 \mathrm{~m} \times 2.5 \mathrm{~m}$ each. Thus, the total number of unit plot was $60(20 \times 3)$. The distance maintained between two unit plots was $0.5 \mathrm{~m}$ and between blocks was $1 \mathrm{~m}$. Nitrogen was applied accordingly experimental specification in the form of urea at three splits application. Five hills were randomly selected and marked with the bamboo sticks in each unit plot excluding border rows to record the data on yield contributing characters and yield. Recorded data were analyzed statistically using "Analysis of Variance Technique and the differences among treatment means were adjudged by Duncan's Multiple Range Test (DMRT).

\section{Results and Discussion}

\section{Effect of nitrogen fertilizer}

Nitrogen fertilizer significantly influenced crop characters, yield and yield contributing characters of T. aman rice cv. BRRI dhan 46 . It was observed that $80 \mathrm{~kg}$ $\mathrm{N}$ ha ${ }^{-1}$ produced tallest plant $(113.00 \mathrm{~cm})$, highest number of total tillers hill ${ }^{-1}$ (8.74) and highest number of effective tillers hill ${ }^{-1}$ (6.19). These findings corroborate with those reported by Uddin et al. (2013). $\mathrm{N}_{0}$ (no nitrogen fertilizer control) treatment produced the shortest plant height $\left(106.00 \mathrm{~kg} \mathrm{~N} \mathrm{ha}^{-1}\right)$, lowest number of total tillers hill ${ }^{-1}(7.20)$ and lowest number of effective tillers hill ${ }^{-1}(5.00)$ (Table 1). It was observed that number of total tillers hill ${ }^{-1}$ decreased progressively with the decrease in the amount of nitrogen fertilizer and became lowest at $\mathrm{N}_{0}$ (Control) treatment (Table 1). The highest number of grains panicle ${ }^{-1}(114.20)$ and highest weight of 1000-grains $(25.85 \mathrm{~g})$ was found in $\mathrm{N}_{2}\left(80 \mathrm{~kg} \mathrm{~N} \mathrm{ha}^{-1}\right)$ treatment and the lowest one was obtained from $\mathrm{N}_{0}$ (no nitrogen fertilizer control) treatment (Table 1). Grain yield varied from 3.52 to $4.00 \mathrm{t} \mathrm{ha}^{-1}$. The highest grain yield $\left(4.00 \mathrm{tha}^{-1}\right)$ was obtained from $\mathrm{N}_{2}\left(80 \mathrm{~kg} \mathrm{~N} \mathrm{ha}^{-1}\right)$ treatment and the lowest one $\left(3.52 \mathrm{tha}^{-1}\right)$ was obtained from $\mathrm{N}_{0}$ (Control) treatment (Table 1). The second highest grain yield was found in $\mathrm{N}_{3}\left(120 \mathrm{~kg} \mathrm{~N} \mathrm{ha}^{-1}\right)$ treatment followed by $\mathrm{N}_{1}$ treatment. The increased grain yield with $80 \mathrm{~kg} \mathrm{~N} \mathrm{ha}^{-1}$ might be due to the cumulative effect of the highest number of effective tillers hill ${ }^{-1}$ and grains panicle ${ }^{-1}$ obtained from the supply of nitrogen for the plants. Similar results were found elsewhere (Singh et al., 2000 and Salahuddin et al., 2009). The highest straw yield $\left(5.25 \mathrm{t} \mathrm{ha}^{-1}\right)$ was obtained from $\mathrm{N}_{2}(80 \mathrm{~kg} \mathrm{~N}$ $\left.\mathrm{ha}^{-1}\right)$ treatment and the lowest one $\left(4.46 \mathrm{t} \mathrm{ha}^{-1}\right)$ was obtained from $\mathrm{N}_{0}$ (Control) treatment (Table 1). Application of nitrogenous fertilizer encouraged vegetative growth of rice in terms of plant height and number of total tillers hill ${ }^{-1}$, which ultimately resulted in the increase of straw yield (Mishra et al., 2003). The biological yield and harvest index also affected significantly due to application of nitrogenous fertilizer.

\section{Effect of weed management}

Weed management significantly influenced the crop characters, yield and yield contributing characters except plant height (Table 2). $\mathrm{W}_{3}$ (three hand weedings at 20, 35 \& 50 DAT) treatment showed superiority in terms of number of total tillers hill ${ }^{-1}(8.61)$, number of effective tillers hill ${ }^{-1}(6.81)$, panicle $(21.92 \mathrm{~cm})$, number of grains panicle $^{-1}(111.10), 1000$-grain weight $(25.52 \mathrm{~g})$ while the lowest values were in unweeded control plots. The highest grain yield $\left(4.23 \mathrm{tha}^{-1}\right)$, straw yield $\left(5.51 \mathrm{t} \mathrm{ha}^{-1}\right)$ and biological yield $\left(9.74 \mathrm{t} \mathrm{ha}^{-1}\right)$ was obtained from $\mathrm{W}_{3}$ (weeding at 20,35 and 50 DAT) treatment. The weeds 
competed with the crop plants for nutrition, water, air, sunlight and space thus reducing yield. The increased yield in weeded crops was contributed by higher number of effective tillers hill ${ }^{-1}$ and higher numbers of grains panicle $^{-1}$ over no weeding treatments. This might be due to the fact that weeding kept the land clean and the soil was well aerated which facilitated the crop for better absorption of nutrients, moisture and solar radiation for higher yield. Effective weed management enhanced production of effective tillers hill $^{-1}$, grains panicle ${ }^{-1}$ which ultimately increased grain yield of rice. Therefore, rice should be kept weed free as much as possible through the life cycle to obtain good yield. Yield variations in rice due to weeding were also observed by many researchers (Chowdhury et al., 1994; Ahmed et al., 1998; Hossain et al., 2002; Islam et al., 2003, Liu et al., 2016).

Interaction effects of nitrogen fertilizer and weed management

Interaction effect of nitrogen fertilizer and weed management did not show significant effect on final plant height, panicle length, no. of grains panicle ${ }^{-1}$, 1000-grain weight and harvest index. The highest number of total tillers hill $^{-1}(9.44)$ and effective tillers hill $^{-1}$ (7.83) was obtained from $\mathrm{N}_{2} \times \mathrm{W}_{3}\left(80 \mathrm{~kg} \mathrm{~N}^{-1} \times\right.$ weeding at 20, 35 and 50 DAT) combination and the lowest one was observed in $\mathrm{N}_{0} \times \mathrm{W}_{5}$ (no nitrogen fertilizer control $\times$ unweeded control) combination (Table 3). Grain yield of transplant aman rice cv. BRRI dhan46 was significantly influenced by the interaction between nitrogen fertilizer and weeding (Table 3 ). Grain yield varied from 3.25 to $4.50 \mathrm{t} \mathrm{ha}^{-1}$. The highest grain $\left(4.50 \mathrm{t} \mathrm{ha}^{-1}\right)$ and straw yield $\left(6.10 \mathrm{t} \mathrm{ha}^{-1}\right)$ was obtained from $\mathrm{N}_{2} \times \mathrm{W}_{3}\left(80 \mathrm{~kg} \mathrm{~N}^{-1} \times\right.$ weeding at 20,35 and 50 DAT) combination and the lowest one was obtained from $\mathrm{N}_{0} \times \mathrm{W}_{5}$ (no nitrogen fertilizer control $\times$ unweeded control) combination (Table 3).Biological yield was significantly influenced by the interaction between weeding and nitrogen fertilizer(Table 3). The highest biological yield (10.60 $\mathrm{t} \mathrm{ha}^{-1}$ ) was obtained from $\mathrm{N}_{2} \times \mathrm{W}_{3}$ (80 $\mathrm{kg} \mathrm{N} \mathrm{ha}{ }^{-1} \times$ weeding at 20, 35 and 50 DAT) combination and the lowest one $\left(7.35 \mathrm{t} \mathrm{ha}^{-1}\right)$ was obtained from $\mathrm{N}_{0} \times \mathrm{W}_{5}$ (no nitrogen fertilizer control $\times$ unweeded control) combination (Table 3).

Table 1. Effect of nitrogen fertilizer on yield and yield contributing characters of T. aman rice cv. BRRI dhan46

\begin{tabular}{lccccccc}
\hline $\begin{array}{l}\text { Nutrient } \\
\text { fertilizer }\end{array}$ & $\begin{array}{c}\text { Plant } \\
\text { height }(\mathrm{cm})\end{array}$ & $\begin{array}{c}\text { No. of total } \\
\text { tillers hill }^{-1}\end{array}$ & $\begin{array}{c}\text { No. of effective } \\
\text { tillers hill }^{-1}\end{array}$ & $\begin{array}{c}1000 \text { grain weight } \\
(\mathrm{g})\end{array}$ & $\begin{array}{c}\text { Grain yield } \\
\left(\mathrm{t} \mathrm{ha}^{-1}\right)\end{array}$ & $\begin{array}{c}\text { Straw yield } \\
\left.(\mathrm{t} \mathrm{ha})^{-1}\right)\end{array}$ & $\begin{array}{c}\text { Harvest } \\
\text { index }(\%)\end{array}$ \\
\hline $\mathrm{N}_{0}$ & $106.00 \mathrm{~b}$ & $7.19 \mathrm{~d}$ & $5.00 \mathrm{~d}$ & $23.42 \mathrm{c}$ & $3.52 \mathrm{~d}$ & $4.46 \mathrm{c}$ & $44.15 \mathrm{a}$ \\
$\mathrm{N}_{1}$ & $108.90 \mathrm{ab}$ & $7.78 \mathrm{c}$ & $5.64 \mathrm{c}$ & $24.10 \mathrm{~b}$ & $3.69 \mathrm{c}$ & $4.91 \mathrm{~b}$ & $42.94 \mathrm{~b}$ \\
$\mathrm{~N}_{2}$ & $113.00 \mathrm{a}$ & $8.74 \mathrm{a}$ & $6.19 \mathrm{a}$ & $25.85 \mathrm{a}$ & $4.00 \mathrm{a}$ & $5.25 \mathrm{a}$ & $43.30 \mathrm{ab}$ \\
$\mathrm{N}_{3}$ & $110.60 \mathrm{a}$ & $8.19 \mathrm{~b}$ & $5.80 \mathrm{~b}$ & $24.54 \mathrm{~b}$ & $3.87 \mathrm{~b}$ & $5.05 \mathrm{~b}$ & $43.44 \mathrm{ab}$ \\
Level of sig. & $* *$ & $* *$ & $* *$ & $* *$ & $* *$ & $* *$ & $*$ \\
$\mathrm{CV}(\%)$ & 4.87 & 2.61 & 3.57 & 3.57 & 2.33 & 3.69 & 2.70 \\
\hline
\end{tabular}

In a column, figures with same letter (s) or without letter do not differ significantly whereas figures with dissimilar letter differ significantly (as per DMRT), ${ }^{* *}=$ Significant at $1 \%$ level of probability; ${ }^{*}=$ Significant at $5 \%$ level of probability. $\mathrm{N}_{0}=$ Control; $\mathrm{N}_{1}=40 \mathrm{~kg} \mathrm{~N} \mathrm{ha}^{-1} ; \mathrm{N}_{2}=80 \mathrm{~kg} \mathrm{~N} \mathrm{ha}^{-1}$ and $\mathrm{N}_{3}=120 \mathrm{~kg} \mathrm{~N} \mathrm{ha}^{-1}$.

Table 2. Effect of weeding on yield and yield contributing characters of T. aman rice cv. BRRI dhan46

\begin{tabular}{lccccccc}
\hline Weeding & $\begin{array}{c}\text { Plant height } \\
(\mathrm{cm})\end{array}$ & $\begin{array}{c}\text { No. of total } \\
\text { tillers hill }^{-1}\end{array}$ & $\begin{array}{c}\text { No. of effective } \\
\text { tillers hill }^{-1}\end{array}$ & $\begin{array}{c}1000 \text { grain } \\
\text { weight }(\mathrm{g})\end{array}$ & $\begin{array}{c}\text { Grain yield (t } \\
\left.\text { ha }^{-1}\right)\end{array}$ & $\begin{array}{c}\text { Straw yield (t } \\
\left.\text { ha }^{-1}\right)\end{array}$ & $\begin{array}{c}\text { Harvest } \\
\text { index }(\%)\end{array}$ \\
\hline $\mathrm{W}_{1}$ & 109.03 & $7.72 \mathrm{~d}$ & $5.22 \mathrm{~d}$ & $24.10 \mathrm{c}$ & $3.52 \mathrm{~d}$ & $4.77 \mathrm{c}$ & $42.50 \mathrm{~b}$ \\
$\mathrm{~W}_{2}$ & 110.05 & $8.03 \mathrm{c}$ & $5.40 \mathrm{c}$ & $24.41 \mathrm{bc}$ & $3.71 \mathrm{c}$ & $4.90 \mathrm{c}$ & $43.07 \mathrm{ab}$ \\
$\mathrm{W}_{3}$ & 111.53 & $8.61 \mathrm{a}$ & $6.81 \mathrm{a}$ & $25.52 \mathrm{a}$ & $4.23 \mathrm{a}$ & $5.51 \mathrm{a}$ & $43.49 \mathrm{ab}$ \\
$\mathrm{W}_{4}$ & 110.56 & $8.32 \mathrm{~b}$ & $5.67 \mathrm{~b}$ & $25.10 \mathrm{ab}$ & $4.01 \mathrm{~b}$ & $5.08 \mathrm{~b}$ & $44.12 \mathrm{a}$ \\
$\mathrm{W}_{5}$ & 106.97 & $7.20 \mathrm{e}$ & $5.19 \mathrm{~d}$ & $23.26 \mathrm{~d}$ & $3.40 \mathrm{e}$ & $4.31 \mathrm{~d}$ & $44.10 \mathrm{a}$ \\
Level of sig. & $\mathrm{NS}$ & $* *$ & $* *$ & $* *$ & $* *$ & $* *$ & $* *$ \\
$\mathrm{CV}(\%)$ & 4.87 & 2.61 & 3.57 & 3.57 & 2.33 & 3.69 & 2.70 \\
\hline
\end{tabular}

In a column, figures with same letter (s) or without letter do not differ significantly whereas figures with dissimilar letter differ significantly (as per DMRT)

$* *=$ Significant at $1 \%$ level of probability; NS = Not significant. $\mathrm{W}_{1}=$ One hand weeding at 20 days after transplanting (DAT); $\mathrm{W}_{2}=$ Two hand weeding at $20 \& 35 \mathrm{DAT} ; \mathrm{W}_{3}=$ Three hand weeding at $20,35 \& 50 \mathrm{DAT} ; \mathrm{W}_{4}=$ Weeding by Japanese rice weeder twice at $20 \& 35 \mathrm{DAT}$ and $\mathrm{W}_{5}=$ Unweeded control. 
Table 3. Interaction effects of nitrogen fertilizer and weeding on yield and yield contributing characters of $T$. aman rice cv. BRRI dhan 46

\begin{tabular}{|c|c|c|c|c|c|c|c|}
\hline $\begin{array}{l}\text { Interaction (nitrogen } \\
\text { fertilizer x weeding) }\end{array}$ & $\begin{array}{l}\text { Plant height } \\
\text { (cm) }\end{array}$ & $\begin{array}{l}\text { No. of total } \\
\text { tillers hill }^{-1}\end{array}$ & $\begin{array}{l}\text { No. of effective } \\
\text { tillers hill }^{-1}\end{array}$ & $\begin{array}{l}\text { 1000-grain } \\
\text { weight }(\mathrm{g})\end{array}$ & $\begin{array}{l}\text { Grain yield (t } \\
\left.\mathrm{ha}^{-1}\right)\end{array}$ & $\begin{array}{c}\text { Straw yield (t } \\
\left.\text { ha }^{-1}\right)\end{array}$ & $\begin{array}{c}\text { Harvest } \\
\text { index }(\%)\end{array}$ \\
\hline $\mathrm{N}_{0} \times \mathrm{W}_{1}$ & 106.10 & $7.11 \mathrm{j}$ & $4.89 \mathrm{ij}$ & 22.89 & $3.37 \mathrm{jk}$ & $4.30 \mathrm{jk}$ & 43.94 \\
\hline $\mathrm{N}_{0} \times \mathrm{W}_{2}$ & 107.30 & $7.33 \mathrm{ij}$ & $4.89 \mathrm{ij}$ & 23.62 & $3.40 \mathrm{jk}$ & $4.48 \mathrm{ij}$ & 43.20 \\
\hline $\mathrm{N}_{0} \times \mathrm{W}_{3}$ & 108.20 & $7.78 \mathrm{fgh}$ & $5.67 \mathrm{def}$ & 24.77 & $3.87 \mathrm{ef}$ & $4.83 \mathrm{fgh}$ & 44.47 \\
\hline $\mathrm{N}_{0} \times \mathrm{W}_{4}$ & 107.20 & 7.44hij & $4.89 \mathrm{ij}$ & 24.01 & $3.72 \mathrm{fg}$ & 4.56hij & 44.93 \\
\hline $\mathrm{N}_{0} \times \mathrm{W}_{5}$ & 101.00 & $6.33 \mathrm{k}$ & $4.67 \mathrm{j}$ & 21.82 & $3.25 \mathrm{k}$ & $4.10 \mathrm{k}$ & 44.22 \\
\hline $\mathrm{N}_{1} \times \mathrm{W}_{1}$ & 108.20 & $7.67 \mathrm{ghi}$ & $5.11 \mathrm{hi}$ & 23.69 & $3.45 \mathrm{hij}$ & 4.72ghi & 42.23 \\
\hline $\mathrm{N}_{1} \times \mathrm{W}_{2}$ & 109.00 & $7.78 \mathrm{fgh}$ & $5.44 \mathrm{efh}$ & 23.75 & $3.57 \mathrm{ghi}$ & 4.92efg & 42.05 \\
\hline $\mathrm{N}_{1} \times \mathrm{W}_{3}$ & 109.90 & $8.44 \mathrm{cde}$ & $6.53 c$ & 24.88 & $4.19 \mathrm{c}$ & $5.41 b c$ & 43.65 \\
\hline $\mathrm{N}_{1} \times \mathrm{W}_{4}$ & 109.40 & $7.89 \mathrm{fg}$ & $5.56 \mathrm{deg}$ & 24.50 & $3.93 \mathrm{e}$ & $5.16 \mathrm{cdef}$ & 43.23 \\
\hline $\mathrm{N}_{1} \times \mathrm{W}_{5}$ & 107.90 & $7.1 \mathrm{j}$ & $5.56 \mathrm{deg}$ & 23.67 & $3.35 \mathrm{jk}$ & $4.35 \mathrm{jk}$ & 43.53 \\
\hline $\mathrm{N}_{2} \times \mathrm{W}_{1}$ & 111.70 & $8.33 \mathrm{de}$ & 5.6def & 26.00 & $3.68 \mathrm{~g}$ & $5.20 \mathrm{cde}$ & 41.44 \\
\hline $\mathrm{N}_{2} \times \mathrm{W}_{2}$ & 113.70 & $8.89 \mathrm{~b}$ & $5.78 \mathrm{de}$ & 26.17 & $4.00 \mathrm{de}$ & $5.15 \mathrm{cdef}$ & 43.72 \\
\hline $\mathrm{N}_{2} \times \mathrm{W}_{3}$ & 115.20 & $9.44 \mathrm{a}$ & $7.83 \mathrm{a}$ & 26.79 & $4.50 \mathrm{a}$ & $6.10 \mathrm{a}$ & 42.45 \\
\hline $\mathrm{N}_{2} \times \mathrm{W}_{4}$ & 114.10 & $9.27 \mathrm{a}$ & $6.33 c$ & 26.46 & $4.25 b c$ & $5.33 \mathrm{~cd}$ & 44.36 \\
\hline $\mathrm{N}_{2} \times \mathrm{W}_{5}$ & 110.30 & $7.78 \mathrm{fgh}$ & $5.33 \mathrm{fgh}$ & 23.83 & $3.57 \mathrm{ghi}$ & $4.46 \mathrm{ij}$ & 44.50 \\
\hline $\mathrm{N}_{3} \times \mathrm{W}_{1}$ & 110.10 & $7.78 \mathrm{fgh}$ & $5.22 \mathrm{ghi}$ & 23.81 & $3.59 \mathrm{gh}$ & $4.87 \mathrm{efh}$ & 42.40 \\
\hline $\mathrm{N}_{3} \times \mathrm{W}_{2}$ & 110.20 & $8.11 \mathrm{ef}$ & $5.49 \mathrm{efg}$ & 24.11 & $3.86 \mathrm{ef}$ & $5.05 \mathrm{deg}$ & 43.32 \\
\hline $\mathrm{N}_{3} \times \mathrm{W}_{3}$ & 112.80 & $8.78 b c$ & $7.22 \mathrm{~b}$ & 25.63 & $4.37 \mathrm{ab}$ & $5.70 \mathrm{~b}$ & 43.40 \\
\hline $\mathrm{N}_{3} \times \mathrm{W}_{4}$ & 111.40 & $8.67 \mathrm{bcd}$ & $5.89 \mathrm{~d}$ & 25.43 & $4.13 \mathrm{~cd}$ & $5.27 \mathrm{~cd}$ & 43.94 \\
\hline $\mathrm{N}_{3} \times \mathrm{W}_{5}$ & 108.70 & $7.60 \mathrm{ghi}$ & $5.20 \mathrm{ghi}$ & 23.73 & $3.42 \mathrm{ij}$ & $4.33 \mathrm{jk}$ & 44.13 \\
\hline Level of significance & NS & $*$ & $* *$ & NS & $*$ & * & NS \\
\hline $\mathrm{CV}(\%)$ & 4.87 & 2.61 & 3.57 & 3.57 & 2.33 & 3.69 & 2.70 \\
\hline
\end{tabular}

In a column, figures with same letter (s) or without letter do not differ significantly whereas figures with dissimilar letter differ significantly (as per DMRT).

$* *=$ Significant at $1 \%$ level of probability; $*=$ Significant at $5 \%$ level of probability; NS $=$ Not significant. $\mathrm{N}_{0}=0 \mathrm{~kg} \mathrm{~N}$ ha $^{-1}$ (control); $\mathrm{N}_{1}=40 \mathrm{~kg} \mathrm{~N}$ ha $^{-1} ; \mathrm{N}_{2}=80 \mathrm{~kg} \mathrm{~N}^{-1}$ and $\mathrm{N}_{3}=120 \mathrm{~kg} \mathrm{~N}^{-1} . \mathrm{W}_{1}=$ One hand weeding at 20 days after transplanting (DAT); $\mathrm{W}_{2}=$ Two hand weedings at $20 \& 35$ DAT; $\mathrm{W}_{3}=$ Three hand weedings at 20, $35 \& 50$ DAT; $\mathrm{W}_{4}=\mathrm{Weeding}$ by Japanese rice weeder twice at $20 \& 35 \mathrm{DAT}$ and $\mathrm{W}_{5}=$ Unweeded control

\section{Conclusion}

For the result of the present study it can be concluded that $80 \mathrm{~kg} \mathrm{~N} \mathrm{ha}^{-1}$ along with three hand weedings at 20 , 35 and 50 DAT may be used to obtain the highest grain and straw yields of transplant aman rice cv. BRRI dhan46. Farmers will follow this suggestion because it will help them to obtain a satisfactory yield. It will also help to determine the optimum nitrogen level, to find out the appropriate weed control treatments and to find out the effect of interaction between nitrogen fertilizers and weed management on the growth and yield of transplant aman rice cv. BRRI dhan 46 .

\section{References}

Ahmed, Z., Khan, D. R., Alim, S. D., Tahir, M. and Marwat, K. B. 1998. Effect of economics of time and weed removal on the yield and yield components of rice. Sarhad J. Agril. 14(4): $335-338$.

Bhuiya, M. S. U., Hossain, S. M. A. and Kabir, S. K. G. 1989.Nitrogen fertilization in rice cv. BR10 after green manuring. Bangladesh J. Agril. Sci. 16(1): 89-92.

BRRI (Bangladesh Rice Research Institute). 2008. Annual Report for 2007. Bangladesh Rice Res. Inst., Joydevpur, Bangladesh. pp. 28-35.

Chowdhury, M. J. U., Sarkar, A. U., Sarkar, M. A. R. and Kashem, M. A. 1994.Effect of weed infestation regime on the growth and yield of transplant aman rice. Bangladesh J. Agril. Sci. 21(1): 141-147.

Hossain, M. M. and Haque, M. Z. 2002. Seedling age and weed density effects on basal tillers survival and yield of transplanted deep water rice. In: Proc. Intl. Deep Water Rice Workshop. Manila. Philippines. pp. 16-20.

Hossain, S. M. A. and Islam, M. S. 2006. Fertilizer Management in Bangladesh. Adv. Agron. Res. Inst., Joydebpur, Gazipur. pp. 48-54.

Hussain, T., Jilani, G. and Gaffer, M. A. 1989. Influence of level and time of $\mathrm{N}$ application on growth and yield of rice. Intl. Rice Res. Newsl. 14(6): 18.

Islam, M. R., Haque, M. S. and Bhuiya, Z. H. 1990.Effect of nitrogen and sulphur fertilization on yield response and nitrogen and sulphur composition of rice. Bangladesh J. Agril. Sci. 17(2): 299-302.

Islam, M. Z. 2003. Effect of weeding regime on the growth and yield of rice. J. Agric. Environ. Sci. 11(5): 640-646.

Liu, X., Wang, H., Zhou, J., Hu, F. and Zhu, D.2016. Effect of $\mathrm{N}$ Fertilization Pattern on Rice Yield, N Use Efficiency and Fertilizer-N Fate in the Yangtze River Basin, China. PLOS ONE 11(11): e0166002.

Mamun, A. A. 1990. Weeds and their control: A review of weed research in Bangladesh. Agricultural and Rural Development in Bangladesh. Japan Intl. Co-operation Agency, Dhaka, Bangladesh. JSARD. 19: 45-72.

Mamun, A. A., Karim, S. M. R., Begum, M., Uddin, M. I. and Rahman, M. A. 1993. Weed survey in different crops under three agro-ecological zones of Bangladesh. BAURES prog. 8: 41-51.

Mishra, P. K., Rajput, R. S., Tripathy, R. K. and Joshi, B. S. 2003. Effect of integrated nitrogen nourishment and growth regulators on yield attributes and grain yield of hybrid rice. Ann. of Agric. Res. 24 (2): 411-415.

Mobasser H. R., Delarestaghi M. M., Khorgami A., Tari, D. B. and Pourkalhor, H. 2007. Effect of planting density on agronomical characteristics of rice (Oryza sativa L.) varieties in North of Iran. Pak. J. Biol. Sci. 10(18): 32053209. 
Patel, S. R. and Mishra, N. N. 1994.Effect of different forms of urea and levels of nitrogen on the yield and nitrogen uptake of rice. Adv. Plant Sci. 7(2): 327-401.

Salahuddin, K. M., Chowhdury, S. H., Munira, S., Islam, M. M., Parvin, S. 2009. Response of nitrogen and plant spacing of transplanted Aman rice. Bangladesh J. Agric. Research. 34(2): 279-285.

Singh, M. K., Thakur, R., Verma, U. N., Upasani, R. R. and Pal, S. K. 2000. Effect of planting time and nitrogen on production potential of Basmati rice (Oryza sativa L). cultivars in Bihar Plateau. Indian J. Agron. 45(2): 300-303.

Singh, T., Singh, T., Singh, T. P. and Sharma, S. 2006. Effect of date of transplanting, plant population and nitrogen level on yield and quality of Basmati rice (Oryzasativa L.).Crop Res. 7(3): 643-646.
Tari, D. B., Pirdashti, H., Nasiri, M., Gaganchian, A. and Hoscini, S. S. 2007. Determination of morphological characteristics affected by different agronomical treatments in rice.(IR 6874-3-2). J. Appl. Biol. Rajendra Agric. Univ. Pusa. India. 6(1-2):48-53.

Uddin, M. H. 2003. Effect of plant spacing and nitrogen levels on yield of transplanted Aman rice cv. BR39.MS Thesis, Dept. Agron. Bangladesh Agric. Univ., Mymensingh. pp. 16-44.

Uddin, S., Sarkar, M. A. R. and Rahman, M. M. 2013.Effect of nitrogen and potassium on yield of dry direct seeded rice cv. NERICA1 in Aus season. Intl. J. Agron. Plant Prod. 4(1): 69-75.

Zhao, L., Wu, L., Wu, M. and Li., Y. 2011. Nutrient uptake and water use efficiency as affected by modified rice cultivation methods with irrigation. Paddy Water environ. 9: 25-32. 